\title{
INTENSITY OF CHANGES IN THE ECONOMIC STRUCTURE AND CHANGES IN GDP DYNAMICS PER CAPITA, AS EXEMPLIFIED BY SELECTED COUNTRIES OF CENTRAL AND EASTERN EUROPE
}

\author{
Joanna RYDROWSKA-KURZBAUER \\ Silesian University of Technology, Faculty of Organization and Management, Department of Economics and \\ Informatics, Poland; joanna.rydarowska-kurzbauer@polsl.pl, ORCID: 0000-0001-7024-9088
}

Purpose: The purpose of the article is to examine the relationship between the intensity of changes in the economic structure and changes in GDP dynamics per capita in selected countries of Central and Eastern Europe.

Design/methodology/approach: The following methods were used in the article: critical literature analysis and statistical data analysis using selected statistical tools. Based on data obtained from World Bank Open Data, the square coefficients of relative structural changes were calculated for four selected countries of Central and Eastern Europe: Czech Republic, Hungary, Poland and Slovakia. The analysis covered almost 30 years, from 1990 to 2018. The results of these studies were then referred to selected theories of structural changes.

Findings: The intensity of structural changes in the analysed period was not homogeneous, both in terms of time and subject. It would be difficult to determine the general trend or regularity in the years studied. Each of the separated time frames was characterised by different characteristics of the analysed variables, within which some similarities and differences between countries were noticed. At the same time, in the analysed years there were some similarities to the regularities described in selected theories of structural changes.

Research limitations/implications: The research carried out in the article is only one aspect of the assessment of changes in the structure of Central and Eastern European countries. For a full picture of them, research should be continued, including in creating and dividing the GDP structure or the employment structure.

Originality/value: The use of the quadratic coefficient of relative structural changes as a measure of changes in the economic structures of Central and Eastern European countries.

Keywords: Changes in the economic structure, intensity of changes in the structure, GDP per capita, Central and Eastern Europe.

Category of the paper: Research paper. 


\section{Introduction}

Changes in the economic structure are a common phenomenon and occur in almost every economy. By adopting structure as a set of many interrelated elements, structural changes can be defined as changes in relations that occur between elements of the system, as well as between them and the entirety. These relations inform about the existence (or not) of references between the states of the elements as well as their properties and characteristics (Mynarski, 1989). These relations can be, for example, as indicated by J. Lisikiewicz, reflected by the relationships between the numbers by which the elements of the structure were characterised (Lisikiewicz, 1977). One then talks about quantitative type relations, illustrating the intensity of changes in the adopted period (Jakóbik, 2000). In addition to quantitative relations, qualitative relations are also taken into account, enabling the study of both the utility and effectiveness of the structure. The result of changes in qualitative relations are changes in the competitiveness and innovativeness of the examined structure or its elements. They allow you to assess the level of development of a given economy as well as the stage of development of its competitiveness. Hence, economic growth and development are inherent issues that accompany structural considerations. There are many interpretations and views in the economic literature as to the relationship between structural changes and growth or development. The literature points to at least three relations: (1) growth - development, (2) structural changes - growth and (3) structural changes - developpment. Expanding point (1), it can be stated that the necessary condition for growth is continuous development. At the same time, growth creates better conditions for development. Z. Dach, however, believes that economic growth is a necessary condition, though not sufficient, for development to occur. In developing countries, for example, growth has been recorded in conditions of non-development. However, the reverse variant is impossible, i.e. development without economic growth (Dach, 2011). The feedback loops between growth and development are also manifested in creating favourable conditions for structural changes. M. Klamut believes that 'economic growth and the accompanying structural changes are collectively referred to as economic development' (Klamut, 2002). The analysis of the literature also indicates the connections mentioned in points (2) and (3). A. Karpiński in his work presented the idea of this relationship in the following way. On the one hand, economic development causes changes in the structure of the developing economic system, on the other, the deeper the changes in structure, the faster the pace of development (Karpiński, 1986). G. Kołodko stated that 'growth entails structural changes for which conditions must be created in the current functioning of the economy' (Kołodko, 1986, p. 34). This view was supplemented by J. Gościeński, adding that structural changes are one of the main goals of growth, and through growth development (Gościeński, 1989). Economic growth is therefore the result of a specific structure and structural changes. At the same time, the nature and growth rate are structure-forming factors, because they 'introduce changes in 
relations within a given structure' (Gościeński, 1990, p. 152). This interconnectedness and interaction of many of its elements makes the phenomenon of structural changes universal, yet very complex and multifaceted, for the description of which you can use various structural cross-sections, coefficients and measures. Observations of structural transformations in many countries have led to the description, quantification and determination of the regularity of these transformations. The detection of certain clear trends prompted many scientists to formulate the theory of structural change. This article only mentions those that pertain to the relationship between the intensity of structural changes and gross domestic product per capita.

$\mathrm{S}$. Kuznets is one of the most important economists mentioned in the context of research on the links between economic growth and changes in structure. He carried out his analysis of structural changes in the creation of a national product over a period of 150 years. During the period under review, he observed the existence of structural similarities in different countries, with varying levels of national income per capita. He noted that with high product growth rates per person, associated with the widespread use of new knowledge and technological innovations in production, it is likely that changes in the production structure will be extensive (Kuznets, 1976). H. Chenery also studied similar relationships. His research covered about 100 countries. He proved that the share of industry increases with the increase of national income per capita, then, after reaching the appropriate level, stabilises and decreases. He also noted that not always the same level of national income per capita must be associated with a similar economic structure. Sometimes, at individual stages of the structural development of the economy, there are differences between countries, the smallest in services and agriculture, while the largest in the processing industry (Chenery, Syrquin, 1975). Together with L. Taylor they observed that the distortions of the described regularities of structural changes may result from the specificity of a given country. For example, they reported that changes in the shares of individual structure elements may occur at different levels of national income per capita depending on the size of the country (Swadźba, 1994). J. Moore and W. Kossow also came to interesting conclusions. Analysing structural changes in several countries, they noticed (Moore, 1978) that sustainable economic growth is accompanied by:

- at a high production growth rate, a small degree of structural change,

- at a low production growth rate, a large degree of structural change.

They stated that changing the structure of produced goods is expensive and complicates production so much that it cannot be accompanied by a high increase in production. The authors in support of this thesis presented the results of conducted research. However, it should be noted that they only concerned individual countries (Wyżnikiewicz, 1987). The quoted research was based on statistical data over a distant period of highly developed economies. The question therefore arises as to their relevance. Hence, the purpose of this article was to examine the relationship between the intensity of structural changes and changes in gross domestic product in the countries of Central and Eastern Europe. 


\section{Research methodology}

The analysis covered four countries of Central and Eastern Europe, Poland, the Czech Republic, Hungary and Slovakia, selected due to their common economic history and geographical location. The data obtained from World Bank Open Data, from 1990-2018, was divided into three time frames. The first, covering the years 1990-2000, i.e. the first decade after these countries began their systemic transformation. The second covers the following years, the preparation and the first years of membership of the European Union, up to the financial crisis in 2008. The scope of the third time frame includes the years from 2009.

The dynamics of gross domestic product per capita, calculated in constant prices from 2010 (in American dollars), was adopted as a measure of the level of national income. Data from 1990-1991 from World Bank Open Data was not available for all countries. However, they were not supplemented with data from other statistical institutions to avoid the problem of their incomparability (due to the use of different calculation methodologies by different institutions). On the other hand, for calculating the pace of changes in economic structures, the square factor of relative structural changes was used. Its cognitive value is relatively greater than other types of coefficients (e.g. linear change coefficients or absolute change coefficients). The relative coefficients of structural changes, in addition to reflecting the differences in the intensity of these changes, are assigned another interpretation in the literature, namely they also characterise the unevenness of the production rate of individual sectors. This factor has been described in the literature by the following formula:

$\sigma=\sqrt{\sum_{k=1}^{n}\left(\frac{f_{2 k}}{f_{1 k}}-1\right)^{2} \cdot f_{1 k}}$

where:

$\sigma-$ Is the quadratic coefficient of relative structural changes,

$k=1,2, \ldots$,

$n$ - production sectors,

$f_{1 k}, f_{2 k}$ - shares of the $k$-th production sector in the periods $t=1$ and $t=2$.

The presented quadratic coefficient of relative structural changes (also referred to and shortened as the intensity factor in this article) in a synthetic way illustrates the intensity of structural changes. It is not a standardised measure because there is no upper limit on the value it can take. It can be assumed that the higher its value, the greater the intensity of changes. The lower the value, the lower the intensity.

In order to show similarities or differences of the analysed variables, a correlation coefficient was calculated for each country and separately for three time frames. This factor can take values from -1 to 1 . The coefficient sign indicates the direction of correlation. In this regard, the sign 'minus' indicates the inverse relationship between the variables studied, 
while positive values indicate the same direction of change. The absolute value of the correlation coefficient shows the strength of this relationship. The higher, closer the level to the unity the coefficient takes, the stronger the correlation is. The value of 'zero' indicates a complete lack of correlation. The charts also indicate trend lines for the intensity of structural changes and dynamic changes in GDP per capita. The type of these lines (exponential, logarithmic, linear, polynomial) was selected in terms of the best fit to the characteristics of variable changes for a given country. All variables have been shown in charts characterising individual time frames. Aggregate data showing the entire analysed period has been included in the statistical appendix.

The results of the research, in each of the three separate time frames, were referred to the patterns observed in the previous part of the article, observed by S. Kuznets, J. Moor and W. Kossow. H. Chenery's theory refers to a more disaggregated economic structure (referring to division into sectors), therefore it will not be taken into account in further considerations.

\section{Assessment of changes in economic structures in the years 1990-1918}

The first stage of the analysis began with very low (negative) values of the GDP per capita product in all the analysed countries of Central and Eastern Europe. By graphically analysing the course of the variables selected for analysis (fig. 1), several relationships can be observed. First of all, after the initial decline in GDP throughout the whole period under review, it increased in all countries. In addition, the ever higher GDP per capita dynamics were accompanied by the decreasing intensity of structural changes. This phenomenon is also confirmed by negative correlation coefficients of this relationship (Table 1 in the statistical appendix). The described situation corresponds to the observations of J. Moore and W. Kossow, when high production growth is accompanied by small structural changes. This could probably be related to the system transformation process that took place in these countries. There was then a slow adaptation and retraining of economic structures to those that characterise highly developed countries. Noteworthy is the Polish economy, for which this period is the period of the highest intensity of structural changes (in the entire analysed time frame). The reason for this situation may be the type of transformation carried out in this country. In the case of Poland, there is talk of the most radical nature of system reforms being carried out compared to other countries. However, Hungary ranks at the other extreme, with the most gradual character. This is also reflected in the lowest factor of structural change intensity (Table 1 in the statistical appendix). 


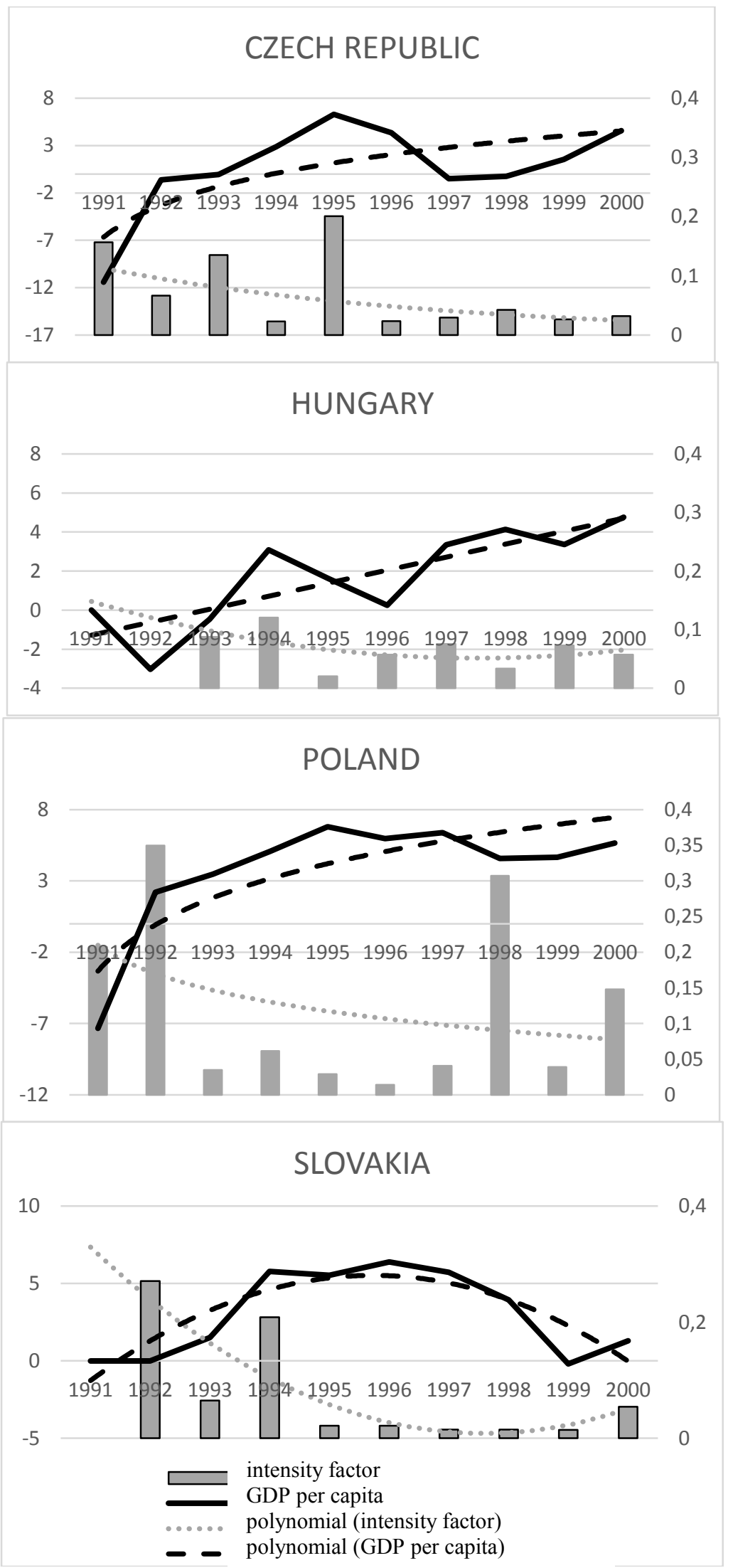

Figure 1. Structural changes in the years 1990-2000. Own study based on World Bank Open Data. 


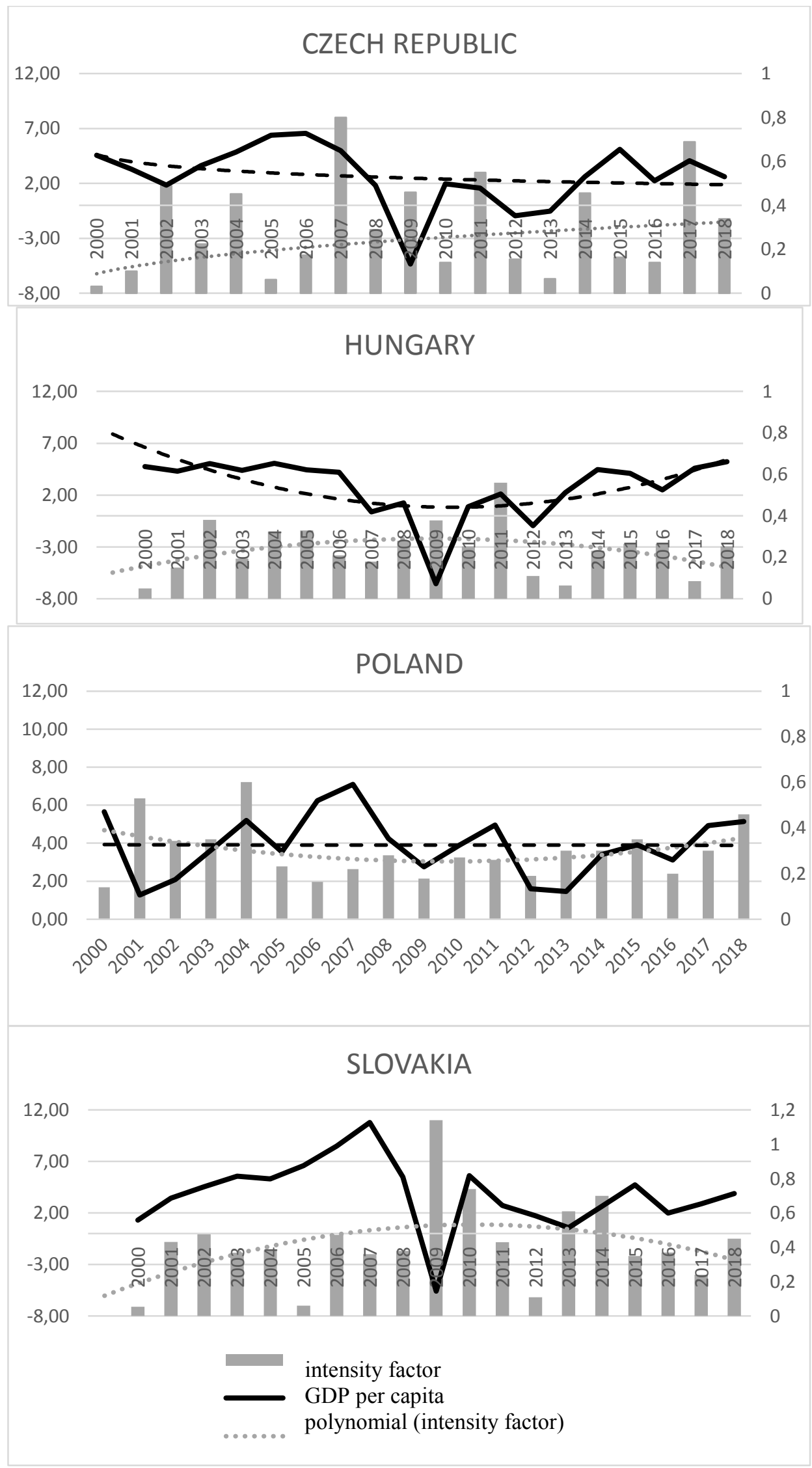

Figure 2. Structural changes in the years 2000-2018. Own study based on World Bank Open Data. 
The second period of analysis is characterised by the continuation of the inverse relationship between the dynamics of GDP per capita and the intensity of structural changes in the Polish, Czech and Hungarian economies. Figure 2 presents this regularity. This is confirmed by both trend lines plotted on the graph and negative correlation coefficients (Table 1 in the statistical appendix). At the same time, in Poland this coefficient reached the highest absolute value, which may mean a greater relationship (correlation) between the examined variables. Again, the phenomena occurring in these economies can be considered as consistent with the results of J. Moore and W. Kossow's research. It should be noted that 2000-2008 is the preparatory period for these countries to join the European Union and the first years of membership in this grouping. This may explain the greater intensity of structural changes and the dynamics of changes in GDP per capita compared to the previous period. Only in the Slovak economy higher production changes were accompanied at that time by an increase in the intensity factor. Hence the positive value of the correlation coefficient (Table 1 in the appendix). This phenomenon is consistent with the research of S. Kuznets, who explained large product changes per capita with deeper structural changes. During this period, larger differences in the dynamics of the analysed variables in individual countries are also noticeable. This can be seen, for example, by the values of the correlation coefficient and intensity factors (Figure 3 in the statistical appendix).

The third time frame began with deep declines in production in all economies (Figure 2). The lowering of the growth rate to negative values was probably caused by the global financial crisis. At the same time, the smallest decline was characterised by the Polish economy, which was the only one among the analysed countries that did not experience a negative GDP growth. What also distinguishes this economy is the low, in this period, intensity factor of structural changes. In addition, the negative and the highest correlation coefficient among the analysed countries (Table 1 in the statistical appendix) shows a large, inverse relationship between the studied variables. Therefore, in this period, the situation of the Polish economy can be compared with the conclusions of S. Kuznets, although it should be noted the reverse direction of these changes. In the remaining countries, 2009 was characterised by very high values of intensity factors at the same time with low GDP per capita. Comparing, with previous years, the Czech, Hungarian and Slovak economies achieved the highest values of these coefficients. The Slovak economy had the highest average coefficient in this period. Such a high intensity of structural changes accompanied the low production growth rate, which makes this period consistent with the results of J. Moore and W. Kossow. 


\section{Summary}

The analysis carried out in the article allows to draw the following conclusions. First of all, changes in the structure, with more or less dynamic, took place in each of the analysed economies. The intensity of these structural changes in the analysed period was not homogeneous, both in terms of time and subject. It is difficult to determine the general trend or regularity in the examined years. Each of the separated time frames was characterised by different characteristics of the analysed variables, within which some similarities and differences between the analysed countries were noticed. The most expressive case is the Polish economy, which is divided by the largest differences compared to other countries. At the same time, changes in the structure of individual economies only to some extent resembled the regularities presented in the theories of S. Kuznets, H. Chenery, or J. Moore and W. Kossow. The most similarities were observed in the analysed structures of Central and Eastern European countries with the studies of J. Moore and W. Kossow, when high intensity factors of structural changes were accompanied by low GDP growth per capita.

\section{References}

1. Chenery, H., Syrquin, M. (1975). Patterns of Development 1950-1970. Oxford: Oxford University Press for the World Bank.

2. Dach, Z. (2011). Rozwój społeczno-gospodarczy w teorii ekonomii. Kraków: Zeszyty Naukowe Uniwersytetu Ekonomicznego.

3. Gościński, J.W. (1990). Polityka gospodarcza kluczem do reformy rynkowej. Warszawa: PWN.

4. Jakóbik, W. (2000). Zmiany systemowe a struktura gospodarcza w Polsce. Warszawa: PWN.

5. Karpiński, A. (1986). Restrukturyzacja gospodarki w Polsce i na świecie. Warszawa: PWE.

6. Klamut, M. (2002). Poszukiwanie ścieżki trwałego wzrostu. In: B. Winiarski, Polityka gospodarcza. Warszawa: PWN.

7. Kołodko, G. (1986). Cele rozwoju a makroproporcje gospodarcze. Warszawa: PWE.

8. Kuznets, S. (1976). Wzrost gospodarczy narodów, produkt i struktura produkcji. Warszawa: PWE.

9. Lisikiewicz, J. (1977). In: J. Lisikiewicz, Struktura produkcji przemystowej. Metody badania i kierunki zmian. Warszawa: PWE.

10. Moore, J.A. (1978). The Review of Income and Wealth. Measure of Structural Change in Output. 
11. Mynarski, S. (1989). Elementy teorii systemów i informacji. Kraków: Akademia Ekonomiczna.

12. Swadźba, S. (1994). Zmiany w strukturze gospodarczej Wspólnoty Europejskiej. Katowice: Akademia Ekonomiczna.

13. World Bank Open Data.

14. Wyżnikiewicz, B. (1987). Zmiany strukturalne $w$ gospodarce. Prawidłowości i ograniczenia. Warszawa: PWE. 


\section{Statistical appendix}

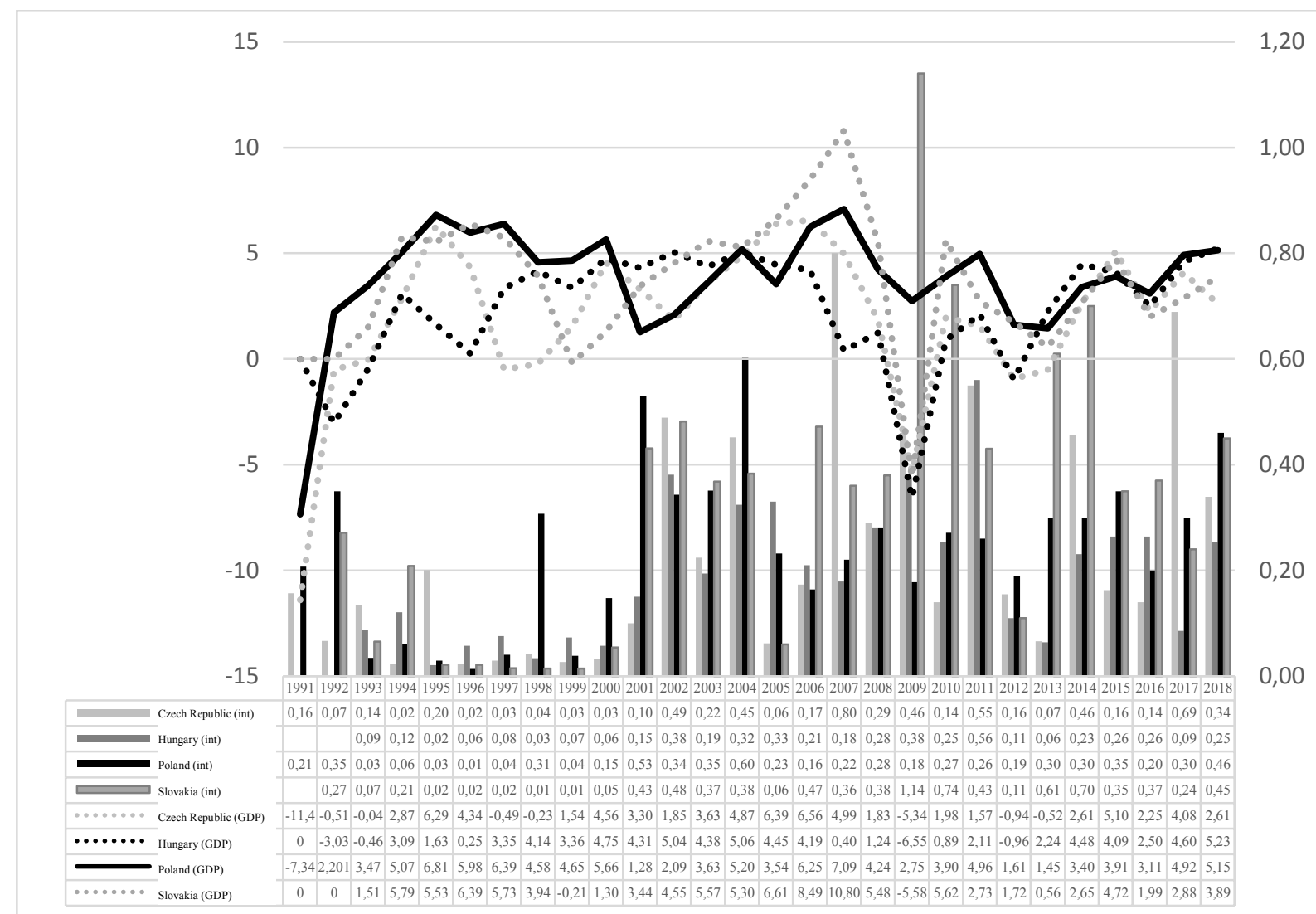

Figure 3. Structural changes (int) and dynamics in GDP per capita (GDP) in Central and Eastern Europe. Own study based on statistical data from World Bank Open Data.

\section{Table 1.}

Average square coefficients of intensity of relative structural changes and correlation coefficients in the countries of Central and Eastern Europe

\begin{tabular}{|l|c|c|c|c|c|c|}
\hline \multirow{2}{*}{ Country } & \multicolumn{2}{|c|}{ Average intensity factor in the years: } & \multicolumn{2}{c|}{ Correlation coefficient in the years: } \\
\cline { 2 - 7 } & $\mathbf{1 9 9 0 - 1 9 9 9}$ & $\mathbf{2 0 0 0 - 2 0 0 8}$ & $\mathbf{2 0 0 9 - 2 0 1 8}$ & $\mathbf{1 9 9 0 - 1 9 9 9}$ & $\mathbf{2 0 0 0 - 2 0 0 8}$ & $\mathbf{2 0 0 9 - 2 0 1 8}$ \\
\hline Czech Republic & 0.067 & 0.291 & 0.320 & -0.257 & -0.178 & 0.052 \\
\hline Hungary & 0.066 & 0.230 & 0.246 & -0.075 & 0.123 & -0.243 \\
\hline Poland & 0.339 & 0.318 & 0.280 & -0.4250 & -0.498 & 0.554 \\
\hline Slovakia & 0.076 & 0.332 & 0.514 & -0.167 & 0.301 & -0.574 \\
\hline
\end{tabular}

Note. Own study based on statistical data from World Bank Open Data. 